\title{
Role of Gene Expression Techniques in Fisheries and Aquaculture
}

\author{
P. Yuvarajan ${ }^{1 *}$, S. Felix ${ }^{1}$, A. Uma ${ }^{1}$ Mahadevi $^{1}$, B. Ahilan ${ }^{1}$ and P. Banupriya ${ }^{2}$

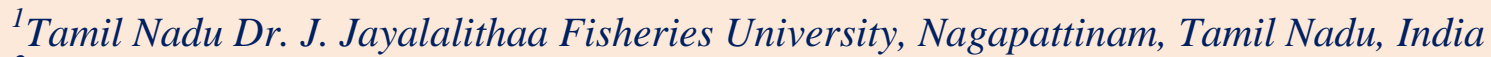 \\ ${ }^{2}$ Vivekanandha College of Arts and Sciences for Woman, Periyar University, Namakkal, \\ Tamil Nadu, India
}

*Corresponding author

\begin{abstract}
A B S T R A C T
\section{Keywords}

Gene expression techniques, Fish gene, Wild stock assessment,

Transcription,

Translation

Article Info

Accepted:

20 June 2019

Available Online:

10 July 2019

\section{Introduction}

Fish is a healthy diet which is more demand in global market. Due to over exploitation, capture fish production has been decreased. To curtail this problem, aquaculture is the solution to fulfill the healthy food (Yuvarajan et al., 2018). To focus on exploited wild stocks should be admitted to biodiversity and genomic study to find out genetic variation. Population genetic study is a useful tool to identification of fish stocks. Genomic study deals with the evolution, structure and function of the gene (Lockhart and Winzeler, 2000). Gene is defined as a sequence of nucleotide/ segment of chromosome/ unit of

heredity. Genes encode proteins and proteins dictate cell function. Therefore, thousands of genes expressed in a particular cell function. The genetic information stored in DNA which is expressed by the process of transcription and translation (Lockhart and Winzeler, 2000). Transcription (DNA to mRNA) process occurs in the nucleus of the cell which genetic information encoded in DNA which is transferred to RNA (https://www.nature.com/scitable/topicpage/g ene-expression-14121669). RNA carries this information out of the nucleus and into the cytoplasm where it becomes directly involved with protein synthesis via translation (Birnstiel et al., 1985). Translation follows
\end{abstract}


the movement of mRNA to the cytoplasm where it interacts with structures called ribosomes to synthesize a protein. Translation of the mRNA at the ribosomes in the cytoplasm then involves several components including other types of RNA including tRNA and rRNA (Freeman, 2009). Functional genomics scrutinizes the biochemical and physiological role of gene products and their interactions and expression. Comparative genomics examines entire genomes, structure, evolution and taxonomy. Environmental genomics comprises molecular variation in natural or artificial populations of different taxa and their response to environmental conditions (Nielsen and Pavey, 2010). Present review paper explores the concept and application of gene expression techniques and genomics study with special reference to fisheries and aquaculture.

\section{Study of gene expression by using various techniques}

Nowadays, the role molecular techniques in fisheries research have increased. The genetic research including stock identification and differentiation study (Park et al., 1993), source of pathogen and their confirmation study (Meyers et al., 1992) and gene expression with reference to growth and gonadal maturation (Duguay et al., 1992). The following methods are used to study the gene expression.

Northern blotting is used to detect specific RNA molecules present within a RNA mixture, employed in the analysis of RNA sample from a cell type or tissue so as to determine the RNA expression of certain genes (Place and Hofmann, 2005). Western blotting is used to detect the specific protein molecules present within a protein mixture. This mixture might include all the proteins that are associated with a certain cell type or tissue. The technique also to determine a protein's size, and how much of it is expressed (Morash et al., 1999). Fluorescent in situ hybridization (FISH) is a cytogenetic technique that can be used to recognize and locate specific gene sequences. FISH can be used to visualize copy number aberrations such as the deletion, translocation or amplification of chromosomes (Levskyand Singer, 2003). Reverse transcription polymerase chain reaction (RT-PCR) is the most sensitive technique available for detecting and quantifying mRNA. Extremely small sample sizes can be used in the quantification of mRNA (Winer et al., 1999). Serial Analysis of Gene Expression (SAGE) is a technique used to generate a library of short sequence tags which can be used to detect a transcript. The transcript expression level can be determined by evaluating how many times each tag is detected.

This technology helps in expression analysis across the genome (Velculescu et al., 1995). DNA microarrayis also called as DNA chip or biochip. It has solid surface to which a collection of microscopic DNA spots are attached. The microarrays are used to determine the expression levels across a large number of genes or to perform genotyping across different regions of a genome (Douglas, 2006). A tiling array is a kind of microarray chip, with labelled DNA or RNA targets hybridized to probes attached to a solid surface. Tiling arrays probe for sequences known to be present in a contigious region. This can provide information about regions that are sequenced (Mockler and Ecker, 2005). RNA Sequencing method is used to measure the sequence of RNA molecules. For examples, shotgun sequencing of cDNA molecules got from RNA through reverse transcription and technologies used to sequence the RNA molecules from a biological sample. So that the primary sequence and abundance of each RNA molecule can be determined (Marioni, 2008) 


\section{Gene expression in aquaculture management}

Gene expression techniques significantly contributing in sex determination system, fish farmers interested in monosex culture to obtain higher production at the same time avoid the breeding (e.g. triploidy). Several microsatellite markers are linked to the sexdetermining factor for linkage analysis (Woram et al., 2003; Nielsen and Pavey, 2010).

Aquaculture genomic studies mainly focus on improved growth and development rates, food efficiencies, increased resistance to disease and pathogens and molecular phenotypic selection for improved brood stock characteristics (Baerwald et al., 2008). Differential gene expression has been used to solve production problems in commercially valuable fish species, such as Atlantic halibut (Hippoglossushippoglossus) during the early stages of aquaculture development by using microarray analyses.

Culture-developed molecular tools can switch vital information and technologies ragards to conservation and management of hatchery and wild fish populations (Nielsen and Pavey, 2010). Gene regulation and expression are thought to play significant roles in adaptive evolution in fishes (Cresko et al., 2004). Genetic mechanisms underlying adaptive differences in important physiological traits (Garcia de Leaniz et al., 2007). Gene expression profiles and physiological genomics applied can be applied to aquaculture and fisheries by developing new technologies and significantly change the way culture management uses genetic information. An innovative cost effective feeds can be developed by using nutrigenomics. For example, plant based protein for carnivorous fish or low fish meal protein feed can be developed.
An implementation of genomic approaches should be encouraged in the fields of fisheries and aquaculture by supporting the development of genomic resources such as linkage maps, expressed sequence tag databases and expression profiling. Genomic and gene expression studies significantly help to nativity of stock identification, to promote the fish genetics \& fisheries biotechnology sector.

\section{Acknowledgement}

The authors grateful to Dr. M.G.R Fisheries College and Research Institute, Tamil Nadu Dr. J. Jayalalithaa Fisheries University, Ponneri, Tamil Nadu, India for providing informative library for collecting references.

\section{References}

Baerwald, E.F., D'Amours, G.H., Klug, B.J. and Barclay, R.M., 2008. Barotrauma is a significant cause of bat fatalities at wind turbines. Current biology, 18(16), pp. R695-R696.

Birnstiel, M.L., Busslinger, M. and Strub, K., 1985. Transcription termination and $3^{\prime}$ processing: the end is in site! Cell, 4l(2), pp. 349-359.

Cresko WA, Amores A, Wilson C, Murphy J, Currey M et al., 2004. Parallel genetic basis for repeated evolution of armor loss in Alaskan three spine stickleback populations. Proc. Nat. Acad. Sci. USA 101: 6050-6055.

Douglas SE, 2006. Microarray studies of gene expression in fish. OMICS 10: 474-489.

Duguay, S.J., Park, L.K., Samadpour, M. and Dickhoff, W.W., 1992. Nucleotide sequence and tissue distribution of three insulin-like growth factor I prohormones in salmon. Molecular Endocrinology, 6(8), pp. 1202-1210.

Freeman, R., 2009. What is' translation'? Evidence \& policy: a journal of research, debate and practice, 5(4), pp. 429-447.

Garcia de Leaniz, C., Fleming, I.A., Einum, S., 
Verspoor, E., Jordan, W.C., Consuegra, S., Aubin- Horth, N., Lajus, D., Letcher, B.H., Youngson, A.F. and Webb, J.H., 2007. A critical review of adaptive genetic variation in Atlantic salmon: implications for conservation. Biological reviews, 82(2), pp. 173-211.

https://www.nature.com/scitable/topicpage/gene -expression-14121669

Levsky, J.M. and Singer, R.H., 2003 Fluorescence in situ hybridization: past, present and future. Journal of cell science, 116(14), pp. 2833-2838.

Lockhart, D.J. and Winzeler, E.A., 2000. Genomics, gene expression and DNA arrays. Nature, 405(6788), p. 827.

Marioni, J.C., Mason, C.E., Mane, S.M., Stephens, M. and Gilad, Y., 2008. RNAseq: an assessment of technical reproducibility and comparison with gene expression arrays. Genome research, 18(9), pp. 1509-1517.

Meyers, T.R., Sullivan, J., Emmenegger, E., Follett, J., Short, S. and Batts, W.N., 1992. Identification of viral hemorrhagic septicemia virus isolated from Pacific cod Gadusmacrocephalus in Prince William Sound, Alaska, USA. Diseases of aquatic organisms, 12(3), pp. 167-175.

Mockler, T.C. and Ecker, J.R., 2005. Applications of DNA tiling arrays for whole-genome analysis. Genomics, 85(1), pp. 1-15.

Morash, B., Li, A., Murphy, P.R., Wilkinson, M. and Ur, E., 1999. Leptin gene expression in the brain and pituitary gland. Endocrinology, 140(12), pp. 59955998.

Nielsen, J.L. and Pavey, S.A., 2010. Perspectives: Gene expression in fisheries management. Current Zoology, 56(1).

Park, L.K., Brainard, M.A., Dightman, D.A. and Winans, G.A., 1993. Low levels of intraspecific variation in the mitochondrial DNA of chum salmon (Oncorhynchus keta). Molecular Marine Biology and Biotechnology, 2(6), pp. 362370.

Place, S.P. and Hofmann, G.E., 2005. Constitutive expression of a stressinducible heat shock protein gene, hsp70, in phylogenetically distant Antarctic fish. Polar Biology, 28(4), pp. 261-267.

Velculescu, V.E., Zhang, L., Vogelstein, B. and Kinzler, K.W., 1995. Serial analysis of gene expression. Science, 270(5235), pp. 484-487.

Winer, J., Jung, C.K.S., Shackel, I. and Williams, P.M., 1999. Development and validation of real-time quantitative reverse transcriptase-polymerase chain reaction for monitoring gene expression in cardiac myocytesin vitro. Analytical biochemistry, 270(1), pp. 41-49.

Woram, R.A., Gharbi, K., Sakamoto, T., Hoyheim, B., Holm, L.E., Naish, K., McGowan, C., Ferguson, M.M., Phillips, R.B., Stein, J. and Guyomard, R., 2003. Comparative genome analysis of the primary sex-determining locus in salmonid fishes. Genome research, 13(2), pp. 272-280.

Yuvarajan, P., S Felix, Cheryl Antony, AGopalakannan, $M$ Menaga and $S$ Ezhilmathi. 2018. Nursery intensive rearing of GIFT tilapia in outdoor lined pond utilizing aerobic microbial floc technology (AMFT). J. Entomol. Zool. Stud. 6(3), 705-709.

\section{How to cite this article:}

Yuvarajan, P., S. Felix, A. Uma, Mahadevi, B. Ahilan and Banupriya, P. 2019. Role of Gene Expression Techniques in Fisheries and Aquaculture. Int.J.Curr.Microbiol.App.Sci. 8(07): 24352438. doi: https://doi.org/10.20546/ijcmas.2019.807.299 